\title{
Opportunities to Develop Enterpreneurial-Based Development Economy in The Era of Globalization
}

\author{
Andi Cudai Nur \\ Universitas Negeri Makassar (email: cudainur@gmail.com) \\ Slamet Riadi Cante \\ Universitas Tadulako (email: Riadislamet45@yahoo.co.id) \\ Risma Niswaty \\ Universitas Negeri Makassar (email: risma.niswaty@unm.ac.id)
}

\begin{abstract}
This study aims to look at how entrepreneurship in tourism captures opportunities in the Covid-19 phenomenon that is endemic in Indonesia, and explains the essence and orientation of opportunities to develop the potential of leading entrepreneurship-based tourism. The approach used is quantitative and qualitative techniques, related to philosophical considerations, the application of quantitative and qualitative approaches, and the mixing of these two studies in one study. The results showed: 1. Tourism potential in Sinjai Regency, 2. The development of local and foreign tourists in Sinjai Regency. Tourism potential and tourism development in Sinjai need to be supported by the tourism industry based on entrepreneurship in each tourist destination, through several functions, such as preparing various breakthroughs in preparing and overcoming various unexpected problems both now and in the future, such as: regulating the tourism industry by planning activities operational and procedures in carrying out activities with international standards by formulating standardization policies, recommendations and technical guidance, evaluation, reporting and implementation in the development of the tourism industry, also provides professional facilities in the tourism industry with guidance and technical guidance for tourism businesses regarding standardization, norms, criteria and verification, ease of business by mapping and promoting business investment in the tourism industry through coordination, cooperation, in the context of smooth implementation of tasks. Local governments, entrepreneurs and the wider community are expected to capture the various opportunities available to increase sources of income in supporting development.
\end{abstract}

\section{Keywords:}

globalisation; opportunity; development; entrepreneurship

\section{Introduction}

The phenomenon of life in the era of globalization shows a variety of problems that affect various human needs to meet the desires of sustainable living, various innovations generated by researchers and the discovery of various research and breakthroughs written and unwritten to support life in this millennium. Various concepts have been strived to 
support development, ranging from the tourism, health, social, economic, education and other sectors carried out by the government to solve life problems in the country of Indonesia.

The era of globalization pays attention to tourism as one of the main sectors that supports ever increasing economic development, because the tourism sector brings benefits and benefits for a country including Indonesia. As a research location, Sinjai as one of the regencies in South Sulawesi Province that is very potential, consisting of various islands, sea, land, mountains, and fishery products which is quite extensive around $223 \mathrm{~km} 2$ and has a population of 247,789 inhabitants. This area has a promising tourist destination or tourism potential, therefore, the existing tourist destination must be well managed so that it can be a key factor in creating employment, developing the entrepreneurial world, and developing infrastructure and the availability of optimal supporting facilities. Sinjai has many interesting tourist destinations to visit. One of them is Pulau Sembilan which consists of nine islands with very clear sea water. Of the nine islands, Larea-Rea Island is one of the best of Pulau Sembilan. The vast white sand beach and clear sea water make it look exotic. Based on the results of an interview conducted on January 15, 2019, the Head of the Tourism and Culture Office of Sinjai, Yuhadi Samad stated, "for the development of tourism and cultural potential, it was highly responded by the local government," but now we think it is very difficult to develop tourism that only relies on government funding.

The corona virus pandemic that hit the world, including Indonesia, has disrupted many program activities. So that the Indonesian government makes enough decisions to help people to move and do activities at home, ranging from studying, working, to worshiping. A ban on meetings involving many people has also been carried out in Indonesia. People are also asked to keep their distance to avoid this dangerous virus. However, there is one area that must continue to work to meet the needs of the Indonesian people during \#dirumahaja, namely logistics services. Together with its logistics partners, namely Aei, Anteraja, First Logistics, Go-Jek, Grab Express, Janio, Jne, Lion Package, Nss Express, Primatama, and SiCepat, Blibli shows a real commitment so customers can shop \#dirumahaja safely and comfortably. Every element of society, from the government, companies, to individuals who struggle to provide assistance to others. The government strives to fulfill responsibilities in maintaining social, economic, tourism and health stability by implementing digitalization in various activities both in government administration and in employers by maintaining 
sanitation of operational facilities, ensuring employee health, sending without contact, and ensuring product availability (kompas.com/read/2020/03/31/225204728/ together- we can-).

The International Monetary Fund (IMF) called the economic crisis 2020 as the worst since the "Great Depression" of the 1930s, the cause was a virus called SARS-CoV-2 or known as corona. The virus that causes Covid-19 disease is thought to have spread since December 2019 in China, then spread throughout the world. Until the end of April, the number of cases received reached more than 3 million people and the death toll was above 200 thousand people. Related to the state has taken steps to implement the spread of Covid-19, there are those that apply full quarantine (lockdown) or social permit. Factories also agreed to production, shops closed, students and office workers studied and worked at home. Covid19 causes health, education, social and financial problems. The IMF predicts the global economy will fall to minus 3 percent by 2020, this projection is down 6.3 points from the estimated 3.3 percent pegged in January. Economic experts estimate, now much worse, the 2008-2009 financial crisis, which is the crisis only hit developed economies such as North America and Europe. In 2020, almost all countries fell because of Covid-19, including China, India, and Indonesia. The IMF released several reasons this year's crisis was worse than previous crises, more important because the repairs at any pandemic would end. Until now there has not been a single drug and vaccine that has been clinically tested to overcome the corona virus. Related to the country arising, starting from public health problems, the domestic economy is disrupted, external demand is reduced, and a reversal of foreign capital flows. The shadow will be the worst in the world in 2020 began to be felt with economic growth in the first quarter of 2020, as one of the countries with the largest GDP in the world, recorded a growth of minus 6.8 percent. In fact, China's GDP usually grows at around 6 percent in the previous quarters (Andrea Lidwina: 5/8/2020, Health or Economy).

How can viruses affect the world economy? Pierre-Olivier Gourinchas, in an article published in the book Mitigating the COVID Economic Crisis (2020) says that modern economies are like complex networks that are interconnected between employees, companies, suppliers, consumers, banks, etc. "Everyone is an employee, consumer, or lender to another," If one of the networks is affected by a disease or is affected by Covid-19's handling policies, it can affect others. As a result when supplier or buyer countries are affected and a number of others begin to close their territories due to Covid-19, efforts to achieve economic benefits will 
actually be useless. Furthermore Gourinchas said, the crisis facing the world today is a combination of health and economic crises. This is what distinguishes it from crises in the previous period. This places governments everywhere on difficult policy choices. What should be done first? Suppress the spread of the Covid-19 case or save the economy. The two policy choices are conflicting: between losing lives or creating unemployment, so overcoming health and economic problems is equally important. There are many strategies that can be taken to overcome the recession, such as the central bank providing liquidity assistance to the financial sector or through multilateral cooperation. In essence, it is necessary to have the right combination of policies to deal with a pandemic and recession (Mitigating the COVID Economic Crisis, Center for Economic Policy Research: 2020).

Georgieva Managing Director of the IMF, "Based on what we are improving, mitigating the spread of the corona virus is the most effective way to restart the economy". In April 2020, the Indonesian Regional Science Association (IRSA) in April 2020, out of 145 economists who were respondents, asked permission from the government to fix it by using the corona virus to save lives and human health. Although the policy has a negative impact on money, those who contradict the reimbursement for transfers transferred by Covid-19 will instead cause an economic slowdown. The government is expected to increase investment to improve the health system, such as the construction of emergency hospitals, ventilator production, and also personal protective equipment (PPE). Jason Furman, professor at Harvard Kennedy School, a firmly said "protect people now, help the economy recover later." Furthermore, in the midst of improving and improving what is changing, the government needs to be faster and do whatever can be done. "Much is better than too little," (Furman: 2020) Few actions not only harm public health, but can also overcome economic setbacks. There are several things that can be done, such as allocating a health budget. Then provide cash assistance for households and assistance for the business world. Because what needs to be done is to prevent the crisis from accumulating, so that improving the economy does not make the crisis complicated. Basically, the government needs to prevent people or the world trying to change bankruptcy by making sure people still have money to buy while no longer working.

Roberto Gualtieri, Italian Minister of Finance, "Nobody has to lose their jobs because of the corona virus." The sentence which was later added by Alberto Alesina from Harvard 
University and Francesco Giavazzi from Bocconi University, "And if someone loses a job, then their income will be guaranteed until they get a new job." In Indonesia social assistance from government stimulus is not sufficient. The stimulus is given to programs that are already running, namely the Family of Hope Program (PKH) and the Basic Food Supply Card. PKH budget to $\mathrm{Rp} 37.4$ trillion, distributed to 10 million beneficiary families (KPM) from the previous 9.2 million KPM. Grocery recipients also rose 31.6 percent after the budget was increased to Rp 43.6 trillion. These two programs target the poor, but do not include the lower middle class who suddenly lose income and jobs due to the pandemic. "This social protection program is designed by selecting targets based on past income status and assets owned in addition to the current conditions." (Lukita Grahadyarini: 2020).

The tourism sector, which was affected by the Covid-19 pandemic, is entering a new normal era. A paradigm shift is underway and a number of new protocols will be implemented to welcome the new normal conditions in the tourism industry. The new normal era brings new roles, new roads, and expectations in the tourism sector. Digitalization is growing rapidly beyond expectations. The tourism business must adapt to new conditions and reorganize the strategy of the business model so that it can survive in the new normal era, by adjusting technological developments. "The tourism business and its employees must continue to observe and study opportunities for growth. The industry must begin to focus on applying cleanliness, health and safety standards in business operations, "(Wishnutama Kusubandio: 2nd International Virtual Tourism Seminar" Changes of the Tourism Paradigm in The Era of New Normal ", Friday (05/15/2020) .

It will coordinate with the World Travel and Tourism Council (WTTC) to ensure the protocol complies with global standards and has a positive impact on tourists and workers in the tourism sector. The application of cleanliness, health and safety standards in each tourist destination becomes an important standard that will arouse tourist confidence and restore the industry. WTTC President and CEO Gloria Guevara Manzo stated, the Covid-19 pandemic had a major impact on the world travel and tourism industry which had so far contributed greatly to the world economy. Last year, this sector was able to absorb 330 million people worldwide with gross domestic product (GDP) reaching 8.9 trillion US dollars, or growing 3.5 percent. As a result of the Covid-19 pandemic, the number of workers in the travel and tourism sector has resulted in the loss of 100 million jobs, down 31 percent with a value of 2.7 
trillion US dollars. The impact even reached five times compared to the impact of the 2008 global financial crisis. Concrete examples such as the Sanur tourism area in Denpasar City, Monday (05/04/2020), looked deserted. The occurrence of the Covid-19 outbreak affected community activities, including tourism industry activities in Bali. Gloria added, to be able to recover the tourism sector more quickly needed efforts to adapt to the conditions of the Covid19 pandemic. Among them are implementing global protocols related to hygiene, health and safety standards to restore the level of trust between tourists and visitors. Hygienic behavior and health standards will continue after the epidemic. In addition, collaboration between the government and the private sector is also the key to reviving the tourism industry. It is necessary to implement an integrated health check procedure with the contact history of visitors who come, the isolation protocol of infected visitors, or the application of new technology or applications that can monitor the level of crowd in a location.

The natural beauty of the nautical charm of Pulau Sembilan, Sinjai also has the charm of a mangrove forest located in the village of Tongke-Tongke, East Sinjai district. A very beautiful mangrove forest from a distance is a central area of mangrove restoration and learning with an area of 173.5 hectares. Expanse of mangrove forests can be enjoyed by walking through a sturdy iron wood bridge by forming long interconnected alleys. Visitors can also rent a speed boat to get around to enjoy the views of the mangrove forest. Then the peak of Batupake Gojeng which is located at a height so that tourists can see and enjoy the downtown area of Sinjai Regency with beautiful natural scenery. The local government can develop the Sinjai (Mangrove) green mangrove forest in the village of Tongke-Tongke East Sinjai and build and arrange transportation to support travel through a series of nine islands (small islands) that are still part of the Sinjai Regency. Based on a general description of the tourism potential of Sinjai Regency it needs to be mapped to explore local competencies as a basis for developing integrated tourist destinations on the East Coast of South Sulawesi. This study aims to identify, analyze, and explain the essence and orientation of entrepreneurshipbased tourism development in facing various challenges and problems in the future such as endemics that arise now and various problems in the future.

The specific purpose of this research is to analyze and find out how local competencies can be developed as a basis for the development of integrated tourist destinations with technology support to improve the entrepreneurship sector in the eastern region of South 
Sulawesi, particularly in Sinjai. The results of this study also have a number of practical benefits, namely; 1) Factual data and information sources for regional governments in the East Coast region of South Sulawesi, specifically the Sinjai government together with regional organizations (WTO) who lead the sector in developing integrated tourism destinations, thereby supporting increased regional income, expanding employment and introducing local culture at the national and international level; 2) One of the references and resources for (potential) investors and tourists, both on a local and national scale and on an international scale (foreign countries) of integrated tourist destinations on the East Coast of South Sulawesi and especially in Sinjai; 3) The results are academic and practical, as well as a source of information for people in the East Coast Region of South Sulawesi and the Sinjai community, especially regarding the potential and competencies of tourism destinations so that the community supports and helps preserve the tourism destinations in the region.

\section{Methods}

The research sites are in Sinjai Regency and the Sinjai Cultural Tourism Office, located on Jl. Sudirman, Balangnipa, North Sinjai, South Sulawesi. This research was also carried out in several areas such as the Rea Larea Island tourist area, Bakke Tongke-Tongke Forest, Gojeng Batupake Archaeological Park and several tourist areas that have the potential to be developed, due to the vastness of the area. Location of research, quantitative and qualitative approaches are needed to obtain complete information. According to Sugiyono (2014), a combination research method is a research method that combines or tests quantitative and qualitative methods that are used together to maximize the completeness of the data obtained so that it is more valid, reliable, and objective. Application of qualitative and quantitative methods used and procedures to convert research data into mixed methods with sampling strategies in research and validate research data directly. Related to philosophical considerations, the application of quantitative and qualitative approaches, and the mixing of these two studies in one study, this research becomes more complex than simply collecting and producing two types of data that discuss two-party organizations in gathering data about the overall research results and more data greater than quantitative or qualitative research (Creswell, 2014). Collecting data and information at the Tourism Office and linking it with various information from stakeholders as informants, then quantitative data that has been 
completed is then compared with the results of qualitative data, then analyzed into various findings in the form of narratives. To fully understand the problems that occur from existing problems, it is necessary to conduct research using research strategies related to data both simultaneously and sequentially, while the combination is a procedure for connecting data, analyzing data, using a combination of quantitative and qualitative sequential methods or conversion. Furthermore quantitative data that has been obtained at an early stage can be proven, deepened its expansion, and weakened and can also be canceled by applying qualitative methods in analyzing further data so that it is more accurate (Sugiono, 2017: 415).

\section{Results and Discussion}

The Department of Tourism and Culture of Sinjai Regency based on Regional Regulation of Sinjai Regency Number 5 of 2016 concerning Formation and Composition of Regional Apparatus of Sinjai Regency (Regional Sheet of Sinjai District Number 2016 of 2016, Supplement to Sinjai Regency Regional Sheet Number 93). The main tasks and functions of the Department of Tourism and Culture of Sinjai Regency are listed in the Sinjai District Regulations Number 73 of 2016 concerning the Organizational Structure, Position, Main Tasks and Functions and Work Procedures of the Office of Tourism and Culture. The Office of Tourism and Culture must base on National policies, the RPJP, RPJM, RPJPD, RPJMD, and the OPD Strategic Plan. This is in accordance with the mandate of the Minister of Home Affairs Regulation No. 54 of 2010 concerning Implementation of Government Regulation Number 8 of 2009 concerning Stages, Compilation Procedures, Control and Evaluation of Implementation of Regional Development Plans. The Department of Tourism and Culture of Sinjai Regency must prepare the OPD Strategic Plan for the 2013 - 2018 period which is guided by the 2013 - 2018 RPJMD.

Tourism is a community activity outside the residential area in a short time (less than one year) with the aim of taking time (Richardson and Flicker, 2004; Pitana and Diarta, 2009). Tourism business is a business that is interrelated and quite complex, where there are complex relationships between elements in tourism, such as tourists, local governments, local communities, universities, educational communities and nongovernmental organizations (Weaver and Oppeman, 2000; Pitana and Diarta; 2009). Tourists are the main asset in the tourism business. Tourists are visitors whose trips stay more than one night (WTO, 2008), 
tourists are trips with the provisions of a one-night stay, so what is referred to as a vacation trip does not stay at all. The WTO explains that non-permanent trips for recreational purposes, picnics are also called vacation homes (WTO, 2008). In essence, tourists come for vacation (Mc. Kercher, 1993; Sharpley, 2006). Changes in tourism trends that were initially dominated by conventional tourism such as mass tourism which has a more negative impact (Purwanggono and Akiriningsih, 2009). Ecotourism is one form of special demand tourism that emphasizes the moral context as part of tourism (Butcher, 2002; Sharpley, 2006). Ecotourism is one part of the antithesis of mass tourism. In the context of tourism, special interests of tourists are invited to do something in the midst of a positive or enlightening vacation. It is in this special interest tour that the environmental order becomes part of the resource (Darsoprajitno, 2002). A study entitled "Sustainable Tourism Development on the Island: The Gran Canaria Case Study", published by the Journal "Business and Environmental Strategy, 1999" seeks to explain the efforts of stakeholders on the island of Gran Canaria to revive the tourism industry. In general, the tourism industry can increase the number of workers, increase people's incomes, bring up development infrastructure in the region, so as to encourage the economy in a region (Liu et al, 1987). The majority of the tourism industry focuses on the exploitation of natural beauty. Island-based tourist locations have advantages because they offer new things to tourists who come from urban areas. Sunrise and sunset and sand and wave beaches are the main offerings of the island's tourist sites.

The Development of Destinations and Tourism Industry in Sinjai is led by the head of the sector that has the main task of assisting the head of department in carrying out the tasks of coordination, facilitation, formulation and implementation of policies, evaluation and reporting in the field of destination development and the tourism industry which has the function of: 1) Formulating policies in the field Development of Tourism Destinations and Industries, develop and grant tourism business licenses and develop natural and cultural tourism resources; 2) Regulate the application of standards, guidelines, procedures and criteria in the field of tourism destination development, development and provision of tourism business licenses and the development of natural and cultural tourism resources; 3) Services to develop tourist destinations, developing and providing tourism business licenses and developing natural and cultural tourism resources; 4) Carry out guidance, technical guidance in the field of tourism destination development, development and provision of 
tourism business licenses and development of natural and cultural tourism resources; 5) Monitor, evaluate and report on the objectives of tourism development, development and provision of tourism business licenses and the development of natural and cultural tourism resources; 6) Carry out coordination and cooperation in the development of tourism destinations, and the development and provision of tourism business licenses and the development of natural and cultural tourism resources; 7) Carry out reporting tasks in the field of development of tourism destinations and industries to the head of department.

The implementation of tasks in the Department of Tourism in its organizational structure appears to be quite a number of parts that play a role such as marketing, promotion, and tourism cooperation, while some tasks include; a) Develop a plan of activities in the tourism sector; b) Develop standard operating procedures in implementation activities in the tourism promotion section; c) To encourage the integration of the development of tourism promotion; d) Conducting tourism promotion development services; e) Develop administrative standards and documents in the implementation of tourism promotion; $f$ ) Conduct technical guidance and evaluation in the field of tourism development and promotion; g) Coordinate in cooperation for the development of tourism promotion; $h$ ) Develop an activity plan for the Cooperation and Inter-Institutional Relations Section; i) Develop standard operating procedures for carrying out activities in the Cooperation and Inter-Institutional Relations Section; j) Prepare a plan of activities in the field of cooperation and relations between tourism institutions and actors for the development and development of tourism; k) Coordinate in cooperation and relations between institutions; l) In collaboration with the Indonesian hotel and restaurant association, the Indonesian Travel Agency Association for tourism services; m) Collaborate with the Indonesian Guides Association for tourism scouting services; n) Cooperate with tourism actors for development and development; o) Cooperate and improve coordination with regional/ central tourism institutions and stakeholders in the context of developing tourism promotion and marketing.

Tourism Potential in Sinjai: Sinjai has beaches, caves, seas, islands, agro-tourism, community cultural history, and events (tourism events). Based on data analysis and information on the results of research and discussion, tourism potential in Sinjai can be seen from three aspects, namely: 1) The potential of natural tourism consists of 35 natural tourism objects spread in each destination district, 2) The potential of cultural and historical tourism 
areas , 3) Man-made tourism potential and special interests, such as: 1) Agro milk tourism industry, 2) Manipi Pasipahahan Green Park, 3) Agro Vegetable Garden Tourism, 4) Special Agro Tourism Interest, 4) Special Interest in Mount Bawakaraeng Climbing , 5) Park Agro Tourism, 6) View from the height of Gojeng, 7) Appareng River, 8) Gellert Sports and Families, 9) Expert Crafts, 9) TPI Culinary, 10) TPI Lappa Culinary, 11) H. Muh Nur Tahir Swimming Pool, 11) Batumimbalo Welcome Sculpture, 12) Tallasa Sports and Baths, 13) Park City Forest, 14) Yosemite National Field, 15) Horse Sculpture Park, 16) Sinjai Regional Culinary Course. Potential of Man-Made (Man-Made) Travel and Special Interests: The potential of artificial (artificial) tourism and the potential for tourism of special interest can also be enjoyed by tourists when visiting Sinjai. The potential referred to in this case is nature tourism activities such as beaches and trips to the island, mountain scenery by combining special interest in rock climbing on natural tourism which has become the belle of potential tourist destinations characteristic of the Sinjai Tourist market. In general, both foreign and domestic tourists visiting the Sinjai Regency tourism area are distributing main entrances to other cities or provinces to continue tourism activities in Sinjai Regency so that identification of market characteristics must see the development of tourist destinations in the area of interest. The response of tourists to the availability of food and beverage choices is limited to the purchase and sale of culinary products on grilled fish, and traditional foods that have not varied how to processing and presentation. Restaurants and cafes that provide other traditional culinary are not suitable in terms of comfort and cleanliness, and lack of souvenirs so that tourists who visit Sinjai district can only buy souvenirs in the form of fruits, fish and other seafood. and Sinjai specialty drinks. Furthermore, accessibility focuses on providing facilities and infrastructure to reach tourist destinations such as good roads, the availability of various means of transportation both land, sea and air, as well as providing road signs to the tourist sites. Then, amenitas focus on the availability of various supporting facilities to support tourists while in tourist destinations such as restaurants, lodging, souvenir shops, food/drink shops, health facilities, and entertainment facilities. Various phenomena in the character of the needs of the tourism market require entrepreneurs to be actively involved in providing various tourism facilities. This is a strategic enough opportunity to be developed by the local government by involving the community and cooperating with the business world. The development of entrepreneurship in development, especially tourism, must continue to be 
managed by the local government to its full potential, because the central government has provided various supports to advance the world of tourism. "This sector may become Indonesia's core economy because it is one of the key factors in efforts to increase export service revenues, the creation and expansion of employment, and the development of business technology in entrepreneurship". As entrepreneurship covers all aspects of work, both private and government employees (Soeparman Soemahamidjaja, 1980). The following is an overview of the state of entrepreneurship in South Sulawesi.

Picture 1.

Number of Entrepreneurial Activities in South Sulawesi Year 2020

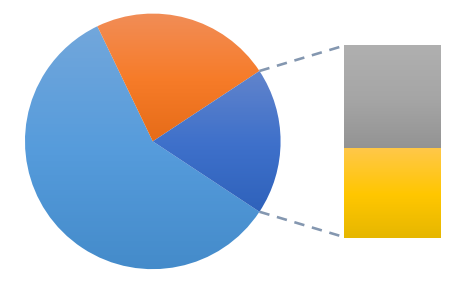

Kuartal Ke-1 $\square$ Kuartal Ke-2

Kuartal Ke-3 Kuartal Ke-4

Entrepreneurs are those who make creative and innovative efforts by developing ideas, and gathering resources to find opportunities and improvement (Prawirokusumo, 1997). Entrepreneurship (entrepreneurship) appears when an individual dares to develop new businesses and ideas. The entrepreneurial process includes all functions, activities and actions related to obtaining opportunities and creating business organizations (Suryana, 2001). The essence of entrepreneurship is to create added value in the market through the process of combining resources in new and different ways in order to compete. According to Zimmerer (1996: 51), added value can be created in the following ways:

1. Development of new technology (developing new technology),

2. The discovery of new knowledge (discovering new knowledge),

3. Improvement of existing products (goods and services), improving existing products or services,

4. Finding different ways of providing more goods and services with fewer resources (finding different ways of providing more goods and services with fewer resources). The following is an overview of entrepneurial activities in South Sulawesi: 
Picture 2.

Entrepreneurial Activities in South Sulawesi Year 2020 On Line Based

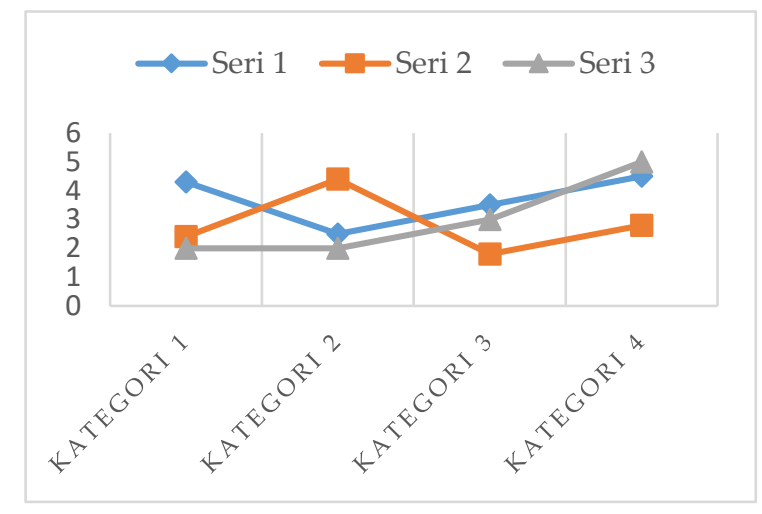

The next opportunity is the attention of the central government which has provided several alternative financing for the tourism sector through credit financing (either commercial loans or KUR), investments and grants, Integrated Tourism Investment Funds (RDPT), and liquidity facilities for housing finance, lodging and tourist village homestays. Various regulations in the financing system have also been given by the central government in various alternative choices, for example in 2018 the government has reduced the KUR interest rate from 9\% per year to 7\% per year. KUR 2018 distribution until August 31, 2018 has reached Rp 88 trillion, with NPL of $0.05 \%$ (70.8\% of the target in 2018 of Rp 123.631 trillion). KUR still dominates for the Micro KUR scheme (66.7\%) followed by the Small KUR scheme (33\%) and the KUR TKI (0.3\%). Meanwhile, total realization of KUR from August 2015 to 31 August 2018 of Rp 300 trillion to Rp 127 trillion in circulation to 12.7 million borrowers. KUR is still quite still followed by sustainable credit quality with a NPL rate of $1.19 \%$ KUR. The central government has provided opportunities and efforts to assist local governments in the field of local tourism development. 8\% of the target in 2018 of Rp 123.631 trillion). KUR still dominates for the Micro KUR scheme (66.7\%) followed by the Small KUR scheme (33\%) and the KUR TKI (0.3\%). Meanwhile, the total realization of KUR from August 2015 to 31 August 2018 amounted to $\operatorname{Rp} 300$ trillion to $\mathrm{Rp} 127$ trillion in circulation to 12.7 million borrowers. KUR is still quite still followed by sustainable credit quality with a NPL rate of $1.19 \%$ KUR. The central government has given great opportunities to regional governments in the field of tourism development. 8\% of the target in 2018 of Rp 123.631 trillion). KUR still dominates for the Micro KUR scheme (66.7\%) followed by the Small KUR scheme (33\%) and the KUR TKI (0.3\%). Meanwhile, the total realization of KUR from August 2015 to 31 August 2018 
amounted to Rp 300 trillion to Rp 127 trillion in circulation to 12.7 million borrowers. KUR is still quite still followed by sustainable credit quality with a NPL rate of $1.19 \%$ KUR. The central government has given great opportunities to regional governments in the field of tourism development. KUR is still quite still followed by sustainable credit quality with a NPL rate of $1.19 \%$ KUR. The central government has given great opportunities to regional governments in the field of tourism development. KUR is still quite still followed by sustainable credit quality with a NPL rate of $1.19 \%$ KUR. The central government has given great opportunities to regional governments in the field of tourism development.

Tourist activities undertaken by travelers, the most popular type of tourist attraction by tourists, are visiting beautiful panoramic beaches, especially at dusk (sunset) and mountain views stretching throughout the Sinjai Regency. Then the next activity fell on the most desirable culinary choices during a visit to the Sinjai district, which largely indicated that travelers chose traditional Indonesian food and drinks and seafood. Because the choices are still lacking in the variety and variety of decent (representative) restaurants, are still limited, and traditional food and beverage sales. Local governments are expected to more aggressively seize the opportunities available to accommodate various concepts and systems of local tourism development, namely to synergize with local, national and international entrepreneurs. Local governments must actively absorb the available funds, especially to support small businesses such as packaging and distribution of milk dairy fish, anchovies, fresh fish and smoked fish. Tourism development in Sinjai Regency has the potential to be developed, this can be seen in the sufficient natural and human resources available. And the development of human resources through various education and training to provide good service standards according to tourism needs. It remains to the attention of the local government to capture various opportunities, The concept of strategy is derived from Classical Greek, namely "strategos" (generals) whose basically ascension is taken from the Greek words for "force" and "lead". The use of Greek verbs related to "strategos" This can be interpreted as "planning and enemies using effective facility-based facilities" (Braker in Heene et al, 2010: 53) Chandler (Triton, 2007: 15) states that the strategy is the formation of the organization's long-term goals, as well as the implementation of a series of actions and allocation of important powers for that purpose. As it is known that strategy is an action that influences and determines the success of programs or activities, both those that have been 
planned and by management. Therefore (Prosperous, 2009: 128) provides an understanding of strategy as a form of rational thought that is systematically regulated, and its formation is based on observations of experience, observations in environmental development (social, economic, political, natural, and scientific) as well as observations of tactics used by people and organizations. Armstrong (Triton, 2007: 16) adding to his presentation with three strategic terms. The first is the declaration strategy, the intention that defines how to achieve the goal by paying special attention to the allocation of resources and empowering and enhancing various capabilities in the external environment. Next, the second, the perspective strategy that explains how critical issues or success factors can be discussed together, as well as making strategic decisions that aim to have a large long-term impact on organizational behavior and success. Finally, the third, namely the strategy of setting goals (strategic goals) and allocating or adjusting available resources with various opportunities (resource-based strategy), so that it can be achieved and there is a strategic match between strategic objectives and various resource bases. Mintzberg (Tikson et al, 2013: 6) identify the meaning of strategy with 5P, namely Plan, Patern, Position, Perspective, and Play.

The aim of strategic management is to create an organization's long-term effectiveness in two environments, namely on the one hand the environment of special authority or the scope of the organization's activities, while on the other hand the development environment is in accordance with its organizational capacity. Thus, strategic management integrates all other management processes with the aim of developing oneself based on a systematic, rational, and effective approach in setting goals and then actualizing organizational goals, monitoring, and evaluating them. Therefore, organizations must try to bring a holistic approach to strategic management, with the understanding that: 1) The attention of the entire organization is focused on unified goals, phenomena and problems that are not addressed by the technical division, and the existence of unequal instructions in the organization; 2) Internal management processes and programs are integrated with achieving the expected results of the organization; 3) Daily and tactical operational decisions are managed together in a flexible boundary line for the achievement of the organization's long-term strategic goals (Poister in Heene 2010: 76). Furthermore, with the slow condition of tourism activities accompanied by a shared disease outbreak, the government must encourage by regulating the tourism system and managing entrepreneurial tourism businesses to capture opportunities in replacing 
entrepreneurial activities that are more in line with conditions such as the use of technology in tourism entrepreneurial activities. Peter F. Drucker said that entrepreneurship is the ability to create something new and different. This definition implies that an entrepreneur is a person who has the ability to create something new, or is able to create something different from something that already exists. Meanwhile, Zimmerer defines entrepreneurship as a process of applying creativity and innovation in solving problems and finding opportunities to improve life (business). From the two opinions above, it can be concluded that entrepreneurship is an ability in terms of creating business activities. Entrepreneurship can be done by: a) Owning capital as well as being a manager; b) Deposit capital and management in the hands of partners; c) Only submitting general personnel is converted into shares as proof of business ownership.

In Indonesia, according to the Digital Indonesia book edited by Edwin Jurriens and Ross Tapsell, digital technology has at least brought great changes in terms of connectivity, diversity, identity, knowledge, and business / trade. The development of digital technology that allows everyone free to use the internet in all respects. In this case government policies are needed to protect the public in the misuse of technology. The world currently faces the current of the industrial revolution 4.0. The rapid development of digital has penetrated various sectors, including the government. Digitalization of the government system, is one form of bureaucratic reform. The Indonesian government, like it or not, must participate in this trend. This was conveyed by World Bank Senior Public Management Specialist Erwin Ariadharma, who was the main speaker at the Reformation Corner. According to him, the current world trend is that each community can get access to every government activity and policy. Free access must also be supported by a single data system or data bank, so there is no confusion in the community. "In the future, digital transparency will become a life based on institutional transparency," Erwin said. The challenge facing Indonesia in developing this digital government is that this system is still partial among government institutions. According to him, the system has not been integrated enough to hamper data dissemination. Erwin emphasized that there must be a common platform that can be managed by all government agencies. Data sharing is important for digital government, as well as a strong commitment to eliminate sectoral egos. "Partial destruction is the minimum level," he added. By capitalizing on the rapid development of cyberspace, governments can serve people 
quickly, safely, effectively and efficiently, without having to be limited by space and time. The acceleration of the implementation of digital governance is important so that Indonesia is able to compete at the world level (Cudai Nur, Andi. Et. All. 2020: 1). Meanwhile Saša Zupan Korže (2019) revealed some of the most important technologies in the tourism technology ecosystem 4.0 of Peceny, Urška Starc et al above. These technologies are IoT (Internet of Things), Big Data, Augmented Reality (AR), Virtual Reality (VR) networks, updating technology-based business models, utilizing mobile technology, Artificial Intelligence (AI) and Robots, as well as other important elements related with AR and VR technology, which is Mixed Reality (MR) technology. Virtual Reality (VR) is a technology that allows users to interact with the environment in the virtual world that is simulated by a computer, so users feel they are in the environment (https://socs.binus.ac.id/2018/ 11/29 /virtual-reality/). Furthermore, there is the term E-commerce which is usually defined as the process of buying and selling a product, where the services and information needed can be done electronically by utilizing a computer network via the internet, which is one part of "electronic business" (Hildamizanthi, 2011). Then Utama (2017) emphasizes the supply chain system from suppliers to factories, buildings, distribution, transportation services to end customers who need company system integration to create supply chain visibility. E-commerce activities in the field of tourism are known as etourism (Ismayanti, 2010), which is a concept of using ICTs to improve the usability, services and marketing of tourism. Furthermore Dickinson et.al. (2012) in Pranita (2018: 246), propose that current tourist destinations must have digital capabilities Industry 4.0. In subsequent developments, the digital economy has become a new phenomenon that shows how important it is to have the ability and skills to use technology to support work to make it easier and faster. Digital economy has a strategic role in the development of the global economy, this argument is proven if we look at the Huawei and Oxford Economics report titled Digital Spillover (2016), the size of the global digital economy has reached 11.5 trillion dollars or about 15.5 percent of world GDP. The magnitude of the contribution of the digital economy to the size of the digital economy can be seen from online trade that has changed the world economic landscape as a "new face" of the global economy, according to the McKinsey report (2018), at least online trade has an impact in four areas. First, financial benefits. Providing exceptional economic benefits for the economy of a country, for example Indonesia as the largest ecommerce market in Southeast Asia. Its value is currently around 2.5 billion dollars and an 
estimated 20 billion dollars by 2022.To maintain the sustainability of business activities, the government needs to provide strategies and reliable problem solving solutions for tourism entrepreneurs to maintain the dynamics of their business activities in various economic problems including health problems (Endemic Covic-19), in social and economic activities, one of which invites business people to implement various methods such as the following, which are 22 ways to keep your business running during a corona outbreak. In essence, you as a business owner can monitor work from home, your employees will be better protected, customers will also feel more secure and comfortable by getting the benefits of easy and fast transactions: 1) Analysis of strategies for doing business/purchasing; 2) Based on data and quality; 3) Dare and make new breakthroughs; 4) Maintain consumer confidence; 5) Show your commitment to consumers; 6) Remain transparent and humane in conducting business; 7) Offering assistance, incentives and rewards; 8) Keep communicating politely and actively to consumers; 9) Take advantage of conducive customer relationship management; 10) Offering a different and interesting experience for consumers; 11) Choose a known local supplier; 12) Take advantage of emergency funds and try to invest goods and services; 13) Distribution of work hours and employee shifts; 14) Provide adequate facilities and equipment for conducting business; 15) Encouraging consumers to use payments digitally and mobile; 16) Give gifts to consumers and promotions to employees in real terms; 17) Focus on sending online services; 18) Maintain consumer confidence by providing optimal services: 19) Providing a varied sales system; 20) Provides various pricing options; 21) Price according to quality; 22) Simple technology-based services.

\section{Conclusion}

The local government has sought to enhance the development of the tourism sector, but still needs to maximize collaborative efforts with all elements of both civil society organizations, the private sector and stakeholders to optimize the use of technology in entrepreneurial activities ranging from small and medium businesses to professional tourism industry activities in the aspect of providing comfort and security for tourism services. Improving the management of the quality of tourist destinations, accommodation, transportation, promotions, souvenirs, culinary delights and tour guides need to receive government attention. The government can accommodate various tourism opportunities to 
increase regional income with a transparent financing system, build a tourism industry network, develop local tourism entrepreneurship through improving the quality of industrial services both nationally and internationally. In addition, policies and strategic plans prepared by the government to develop tourism in a sustainable manner, the next effort is to synergize all available resources by focusing on entrepreneurial activities that are advanced and professionally managed by adopting various technological advances 4.0 in the application of technology-based tourism development entrepreneurs. The tourism potential and tourism development in Sinjai need to be supported by the entrepreneurial-based tourism industry in all tourist destinations, through several functions, such as preparing various solutions to solve problems and break through to overcome unexpected problems both now and in the future. Regulate the tourism industry, planning activities and operational procedures of national and international standards by utilizing technology in various activities, such as in the formulation of standardization policies, recommendations and technical guidance, evaluation, reporting and implementation in the development of the tourism industry. Providing a reliable business network and tourism industry facilities with a variety of technical guidelines for tourism businesses including standardization, norms, criteria, verification, entrepreneurial convenience by mapping and promoting business investment in the tourism industry through a network of coordination, cooperation, monitoring and evaluation. Technology can provide a variety of breakthroughs in management system innovation to deal with various problems that arise such as the case of co-19 epidemic diseases, restrictions on socialization and problems of global economic recession.

\section{References}

Aditama. Manjari, Ratih Melati Eka (2018). Introducing Tourism 4.0: What Is It and How Do We Get Here?

Aditama.Manjari, Ratih Melati Eka (2018). Introducing Tourism 4.0: What Is It and How Do We Get Here?

Aghaei, Sareh., Nematbakhsh, Mohammad Ali., Farsani, H.Adi Kosravi, (2012),Evolution of the World Wide Web: from Web 1.0 to Web 4.0, International Journal of Web and Semantic Technology (IJWesT), Vol 3, No. 1 2012, pp. 1-10 
Andi Cudai Nur \& Muhammad Guntur (2019). Public Policy Analicys. UNM Publishing Agency, Makassar.

Andrea Lidwina: (5/8/2020). Health or Economy. Jakarta: Kompas Dayli Https://Katadata.Co.Id/Analdata.

Aoun, JE (2017). Robot-Froof; Higher Education in the Age of Artificial Intelligence. US: MIT Press.

Baur, C. \& Wee, D. (2015). Manufacturing's Next Act? McKinsey \& Company

Bm Lukita Grahadyarini. (2020) Simalakama Mitigation Covid-19, Health Or Economy? ", Https://Katadata.Co.Id/Analdata/2020/05/08/Simalakama-Mitigation-Covid-19-K Kesehatan-Atau-Ekonomi. Jakarta

Brofenbrenner, U. (1989). Ecological System Theory. In R. Vasta (Ed), Annals of Child Development (Vol.6). Greenwich: CT, JAI Press.

Bungin, Burhan, (2015), Tourism Communication, Kencana Publisher, Jakarta

Creswell, JW (2013). Research Design: Qualitative Approach, Quantitative, and Mixed. Yogyakarta: Student Library.

Cristtie Mill, Robert, (1996). Tourist for The International Business. PT. King Gravindo Persada, Jakarta

Cudai Nur, Andi. et. al. (2020). Partnership, Digitalisation, \& Innovation Public Policy in the Era of Globalization, UNM Publishing Agency. Makassar

Hall CM (2008). Tourism Planning: Policies, Processes and Relationships (2nd ed). Essex, England: Pearson Educated Limited.

Hanief, S., \& Pramana, D. (2018). Media Tourism Business Development with Information Systems. Yogyakarta: Andi.

Heene, A., \& et al. (2010). Public Organizational Strategic Management. Bandung: Refika Aditama.

Hermann, M., Pentek, T., \& Otto, B (2016). Design Principles for Industrie 4.0 Scenarios. Presented at the 49th Hawaiian International Conference of Systems Science.

Hidayat, M. (2011). Planning and Development Strategy Attractions (Case Study Pangandaran beach in Ciamis regency, West Java). The Journal, I (1), 33-44.

Irianto, D. (2017). Industry 4.0; The Challenge of Tomorrow. National Seminar on Industrial Engineering, Batu Malang 
Ismayanti. (2011). Introduction to Tourism. Jakarta: Grasindo.

Jamal T \& Stronza (2019). Collaboration Theory and Tourism Practice in Protected Areas: Stakeholders, Structuring and Sustainability. Journal of Sustainable Tourism 17 (2): 169189.

Jamil, Muhammad (2018). Indonesian Islamic University Library Library Bulletin, 1 (1) 2018, 99-113

Jason Furman, (2020). Harvard Kennedy School, "Protect People Now, Help The Economy Recover Later. Kennedy School:US

Kagermann, H. Wahlster, W., \& Helbig, J. 2013. Recommendations for implementing the Strategic I Industry Initiative 4.0 Working Group, Germany

Kohler, D, \& Weisz, JD. 2016. Industry 4.0: The Challenges of The Transforming Manufacturing. Germany: BPIFrance

Korže, Saša Zupan (2019). From Industry 4.0 to Tourism 4.0. Innovative Issues and Approaches in Social Sciences, Vol. 12, No. 3

Kotler, P., \& Keller, K. (2012). Marketing management, Pearson Education, USA

Kotler, Philip. et al (2017). Marketing 4.0: Moving from Traditional to Digital, Jakarta: Gramedia Pustaka Utama

Lee, J. Lapira, e. Bagheri, B. Kao, H. (2013). Recent Advances and Trends in Predictive Manufacturing Systems in Big Data Enviroment Manuf Lett.1 (1) 38-41.

Lopez, M Tunez., Altamirano V, Valarezo KP, (2016). Collaborative Tourism Communication 2.0: Promotion, Advertising, and Interactivity in Government Tourism Website in Latin America, Revista Latina de Comunicacion Social, Vol 71, pp. 249-271

Main, IGBR (2017). Tourism Marketing. Yogyakarta: Andi.

Main, IGBR (2017). Tourism Marketing. Yogyakarta: Andi.

Moleong, L. (2001). Qualitative Research Methods. Bandung: Teen Rosdakarya.

Nawawi, H. (2012). Strategic Management: Non-Profit Government Sector Organizations. Yogyakarta: Gadjah Mada University Press.

Pearlson, Keri E, and Saunders, Carol S (2010). Managing and Using Information System; a Strategic Approach, USA, Wiley

Peceny, Urška Starc, Jurij Urbančič, Simon Mokorel, Vesna Kuralt \& Tomi Ilijaš (2019). Tourism 4.0: Challenges in Marketing a Paradigm Shift. IntechOpen 
Pereira, AC \& Romero, F. (2017). A review of the meanings and implications of the Industry 4.0 Concept. Procedia Manufacturing 13, pp. 1206-1214.

Peter F. Drucker said that entrepreneurship

Peterson, Tom (2018). Artificial Intelligence in travel and tourism

Pierre-Olivier Gourinchas, 2020. Https://Katadata.Co.Id/Analdata/2020/05/08/SimalakamaMitigation-Covid-19-K

Pitana, I Gde, Prof. Dr, M.Sc and Diarta, I Ketut Surya, SP., MA (2009), Introduction to Tourism Science, Andi Publishers, Jakarta.

Prosperous. (2009). Theory of Strategic Management in Government and Development. Bandung: Refika

Rodic, Blaž (2017). Industry 4.0 and the New Simulation Modeling Paradigm, Organizacija, Vol. 50

Rodic, Blaž (2017). Industry 4.0 and the New Simulation Modeling Paradigm, Organizacija, Vol. 50

Sharpley, R (2006). Ecotourism: A Consumption Perspective, Journal of Ecotourism, vol.1 No.2: 7- 22.

Simanjuntak, BA, Cape, F., \& Nasution, R. (2017). Tourism History: Towards Development of Tourism in Indonesia. Jakarta: Indonesian Torch Reader.

Smith, Richard. (2015). Smart Tourism: Linking technology with the tourism resources of city destinations. NHTV University of Applied Sciences, Breda

Sugiono. (2016). Administration Research Methods. Bandung: Alfabeta.

Sugiono. (2017). Research Methods Combined (Mixed Methods). Bandung: Alfabeta.

Suryadana, LM, \& Octavia, V. (2015). Introduction to Tourism Marketing. Bandung: Alfabeta. Suryana, M.Si.2006. Kewirausahaan.Jakarta:Salemba Empat

Suryawan, I Ngurah, (2009), Bali: Post-Colonial, Traces of Violence and Attitudes on Cultural Studies, KEPPEI Press, Yogyakarta.

Thomas W. Zimmerer, Norman M Scarborough (2008), Kewirausahaan dan Wirausaha Kecil, Salemba 4; Jakarta

Tikson, DT, \& et al. (2013). Writing Reports Module: Strategic Management.

Triton. (2007). Applied Strategic Management: Corporate and Business. Yogyakarta.

Utama, I Gusti Bagus Rai, (2017). Tourism Marketing. Yogyakarta: Andi publisher. 
Wishnutama Kusubandio: 2nd International Virtual Tourism Seminar" Changes of the Tourism Paradigm in The Era of New Normal ", Friday (05/15/2020) . Yoeti, OA (2016). Tourism Planning and Development. Jakarta: Balai Pustaka. Policies, Regulations, and On-Line:

Destination Development Strategy Plan and the Tourism Industry Year 2015-2019 Law of the Republic of Indonesia Number 9 Year 1990 Tourism Law of the Republic of Indonesia Number 10 Year 2009 on Tourism https://blog.mokapos.com/agar-bisnis-tapap-bertahan-saat-wabah-corona?hs.amp=true https://www.paper.id/blog/bisnis/peluang-usaha-virus-corona/amp/ https://biz.kompas.com/read/2020/03/31/225204728/bersama-kita-bisa-p restore-indonesia. 